\title{
The Implementation of Mobile Learning for Reading Literacy (Morlisa) for English Teacher training in Semarang
}

\author{
Sri Katoningsih ${ }^{1}$, AT Soegito ${ }^{2}$, Totok Sumaryanto $F^{3}$, Susanto ${ }^{4}$ \\ ${ }_{1,2,3,4}$ Graduate School, Universitas Negeri Semarang, Indonesia \\ ${ }^{1}$ Coresponding email: srikatoningsih12@gmail.com
}

\begin{abstract}
World of education develops dynamically, particularly in creating media, method, and material for learning which is more interactive and comprehensive. In fact, students have only little time in front of computer to do their assignment or reading. It is the weakness of using computer which cannot be brought everywhere they go. It causes inconvenience in suing computer. Otherwise, they use mobile learning, they can do their assignment, send email or add their knowledge by reading web through their gadget. Habit of reading textbook begins to shift, and many students are lazy to read, therefore, as teacher following the development of the world must develop attractive learning media. The use of mobile learning for reading literacy (Morlisa) may help learning process and can be done wherever students are. The result of implementing Morlisa in learning is that students' assignments are completed on time, delighting and enable students to do the assignments and understand the materials. Reading literacy activity can be conducted wherever without considering time. Morlisa is very easy to use and be good media with its strength. There is discussion menu directly with teacher, based on time determined. The material can be seen, understood repeatedly, either written or by video. With Morlisa, the reading literacy skill improves because it is implemented any time.
\end{abstract}

Keywords: mobile learning, reading literacy, English teacher training

\section{Introduction}

Training and development activities are very important things in an organization. There, however, is something that needs to be attended more in a training about funding and time allocation, to get good achievement (Kankam, 2015).

Training and development have impact on performance and productivity of workers. Good training has positive impact on improving performance and productivity of workers (Neelam Tahir, 2014). The most influencing things are training method and training management, purpose, environment, and trainer. The biggest influences in learning are training method and trainer, training management, environment, and materials. It is only several organizations evaluating training deeply because of the difficulty in direct involvement and lack of valid and good instrument model. The most important thing in training program is the experienced manager in planning, motivated member, good public relations and good facility. Training and development can improve creativity and increase competition of an organization Training design and delivering material is important aspect in an organization. Result of study shows that training design and delivering style in training have significant and positive influence on organization performance (Ghafoor et al., 2011).

The use of innovative strategy is more effective in classroom management significantly higher after training, shows that training is very effective in improving teachers' knowledge about classroom management. Training plays important role in building competence and challenging worker in working environment. Training is important in a job helping to improve workers quality and develop organization. Training brings constructive development like motivation to improve work life quality of the workers optimally. Training and development assists in improving workers' behavior and attitude toward job and improve their motivation. Thus, training and development program is an important aspect which must be studied and attended.

Education world develops dynamically, particularly in creating media, method, and material which are more interactive and comprehensive. The media used are book, magazine, tabloid, offline media, radio, $\mathrm{TV}$, and internet as online media it cannot be ignored that media cannot replace teachers, but ignorance behavior toward the development of technology and knowledge is not good behavior. Many students run their time out of 
home. In fact, the students only spend little time in front of computer to do assignment or reading. It is the weakness of using computer which cannot be brought everywhere they go. It causes inconvenience in using computer. It will be different when they use mobile learning, where they can do their assignment, send email or add knowledge by reading web through their gadget (Thornton, 2004). Using modern method and technique integrated in Mobile learning may help learning to be more interesting, interactive, much information available and more flexible. Using Mobile learning is less cost and may help students to study without limitation (Wains, 2008).

Mobile learning is not a new word combination (2 words combined having new meaning), but it is acronym of mobile elearning. Simply, mobile learning means electronic learning with mobile device or using mobile tool like smartphone to access learning electronically (e-learning) (Traxler, 2009). There are three main function of mobile learning in learning process, which is as supplement (addition), complement, and substitution. Students can use their time flexibly in managing learning activity based on their time and daily activity (Majid, 2012). Features of mobile technologies available any time and place, the thing need to be prepared is only chance in formal and informal learning (Comas-quinn, 2009). Mobile learning is a technology using network and its complement tools, then it expands to digital learning channel, getting service, information and source of education wherever and whenever (Yuan Jiugen, 2010)

Mobile learning is a technique using cellular phone and Wi-Fi technology in learning and education. Mobile learning enable students to share their experience in their group (Farooq, 2002). Internet has been developed in learning activity giving good interaction between teachers and students. In fact, internet is not only step to share knowledge and learning content but also to create good learning environment based on the needs in modern era, diverse learnerswhere it engages the learners in many activities such as interactions, collaborations, conversations and problem solving. An Internet enables the elearning to become the state of artfor distance learning over the world and the mobile learning (m-learning) will be the nextgeneration of distance learning. Mobile devices are technologies that can be carried and used everywhere to enable learners accessing knowledge anytime and anywhere. The main target ofthe next generation of the learning systems is to use current and modern technologies to providenew techniques of learning, training and education that will be easy access and available to allwho wish to be part of it. The nomadic computing environment is different from the normal andtraditional distributed systems. In nomadic computing environment there is a diversity of,handheld devices, smart phones and mobile workstations, which enable users to access and useInternet services anywhere (Laria, 2002). Although M-Learning started to be used in supporting a widerange of learning activities there are not much of research done to know the studentsrequirements or understand what types of mobile applications students need to use on theirmobile devices and how an effective mobile educational software can be designed to supportlearning in an educational environments (A.B, 2006)This rapid increasing of mobile devices in the last

Concept of mobile learning is focused on providing online learning class enable teacher and students to have interaction. The interaction includes learning material, discussion room, delivering assignment and assessment announcement. Technology adopted should be effective pedagogically and assessed as a new innovation. Besides, technology given should be easy to access and available by spread distribution in teacher and students environment. Measurement toward readiness is an activity must be done. It is due to the readiness relates to the success of mobile learning implementation. In the context of mobile learning, readiness is understood as willing and ability to hold and participate in mobile learning. Mobile learning readiness includes all stake holders related to the implementation of mobile learning such as teachers, students, holders or education institutions and government as infrastructure and regulation provider.

\section{Method}

The approach used in this study was qualitative so that the study did not use any counting, also known as scientific study emphasizing on the scientific character of the data source. This study described the implementation of Morlisa for English teacher 
training. The study was conducted in state senior high schools (SMA Negeri) in Semarang. The data of the study were collected by interviewing English teachers, giving questionnaires, and studying documents such as books, notes and archives.

\section{Result and Discussion}

The implementation of Morlisa gave impacts on English teacher training. It was a new thing so there are pro and contra opinions about the implementation of Morlisa in a training. The development of technology has created development in learning. Learners are exposed to the mobile tools of technology and communication, and internet has become a new trend supporting mobile learning, known as mobile learning (m-learning) by using mobile device, especially cellular phone. Combination of telecommunication technology and internet support the development of mobile learning or m-learning system in which the clients use mobile device, interact with server that is web server. Despite the fact $\mathrm{m}$ learning is still in pre-development and not fixed, m-learning is estimated to develop quickly in short time. It will be cheaper and more sophisticated. A study showed that learners are comfortable enough to view screen of small tools under 5 minutes. The strength of Morlisa is that it can be used wherever and whenever, it is estimated to engage more learners because m-Learning uses common technology in daily life. In training using Morlisa, time and place independence are important factor which is often emphasized.

Morlisa is a potential alternative to enlarge education access. However, there is still not much information concerning the use of mobile device, especially cellular phone as training media. The factor limiting the use of Morlisa is related to limitation of internet signal power in participants' area. In mlearning, learners use m-learning more in their spare timeor idle time so that the time to access learning is also limited. The current study explores technical aspects of developing software and does not expose other aspects relating to usage and pedagogic implications. Thus, it needs further studies which are more specific. The following scheme is the plot of using Morlisa in training program.

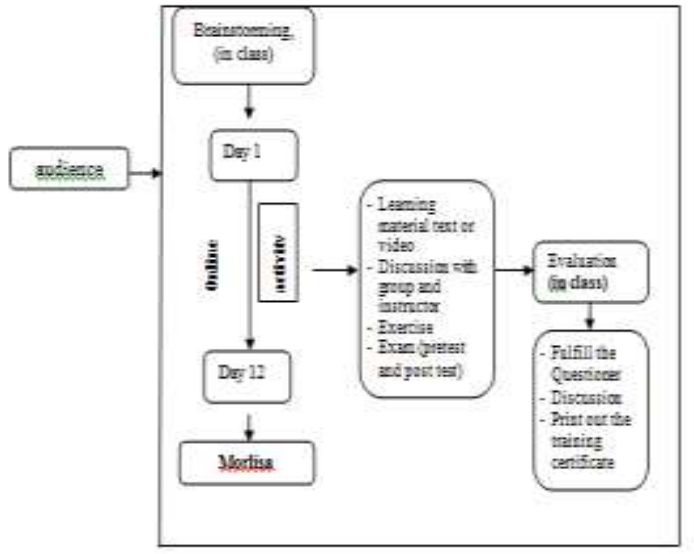

Figure 1. Training program based on Morlisa

The use of Morlisa in training helped its implementation. The participants were $\mathrm{X}$ grade teachers of senior high school because Mobile Learning for Reading Literacy PISA standardized was suitable for 15-year-old students. Training was held in 12 days. The first day, it was delivered the rules and ways in using Morlisa. The meeting was held in 6 hours on the first and the last day. On the second day through eleventh, the meeting was held from in 2 hours. The rest time was used for learning material or doing free assignment of the day. The activity in the second to tenth day was operated by using mobile with their own username given by the instructors in the first meeting. The committee provided fund replacement to buy internet quota. In the main activity, the participants learned material by texts and videos which could be played repeatedly. In the last day (twelfth day), the meeting was closed by direct meeting and giving evaluation during the training. The evaluation included how the training program worked by using Morlisaor a mobile learning system.

Based on the interview and questionnaire result, it showed that the use of Morlisain training brought good impact. Participants could manage their time. They did not leave their class during the training, so it did not make the students skip lessons because the teachers left the class for several days to have training. Teachers could be more focused in following training because the materials could be played or read repeatedly. The group could be connected and had discussion with instructor more directed. The whole questions either pretest or posttest could be accessed directly by Morlisa. By using Morlisa, it is not 
time consuming in training. The most important one was that they did not leave their students in the class. The training manager only gave fund replacement to buy internet quota for the training participants.

\section{Conclusion}

The use of Morlisa improves result of training for English teacher in state senior high school in Kota Semarang. It is caused by the fact that Morlisa is considered easy to be used anywhere and in anyplace. It is efficient in terms of time and cost. A training needs proper strategy to achieve maximum result, and more importantly the teachers do not leave their responsibility for $\mathrm{s}$ teaching.

\section{References}

A.B, D. S. Z. (2006). Mobile Learning In Wireless Classrooms. Malaysian Online Journal of Instructional Technology (MOJIT) 3(2), 16-42.

Comas-quinn, A. M., R,. Valentine, C (2009). Mobile blogs in language learning. Making the most of informal and situated learning opportunities. 1, 96-112.

Farooq, U., Schafer, W, Rosson, M.B and Caroll, J.M. (2002). M-Education: Bridging the Gap of Mobile and Desktop Computing. Centre for Human-Computer Interaction and Department of Computer Science, 1-2.
Kankam, B. a. B., Anthony, dkk (2015). Teachers' perception of authentic assessment techniques practice in social studies lessons in senior high schools in Ghana. International Journal of Educational Research and Information Science 1(4), 62-68.

Laria, G. (2002). Mobile and nomadic user in e-learning: the Akogrimo case, sixth framework programme, Information Society.

Majid, A. (2012). Mobile Learning. Bandung: Universitas Pendidikan Indonesia.

Neelam Tahir, I. K. (2014). The Impact of Training and Development on Employees Performance and Productivity. A case study of United Bank Limited. Peshawar City KPK, Pakistan 44.

Thornton, P. H., C. (2004). Using Mobile Phones in Education. IEEE International Workshop on Wireless and Mobile Technologies in Education. Traxler, J. (2009). Learning in a Mobile Age. International Journal of Mobile and Blended Learning, 1(1), 1-12.

Wains, S. I., \& Mahmood, D. W. . . (2008). Integrating M-Learning with E-Learning.

Yuan Jiugen, X. R., Wang Jianmin. (2010). Applying Research of Mobile Learning Mode in Teaching. International Forum on Information Technology and Applications,. 